\title{
The Impact of Intellectual Capital on the Financial Performance of Non-Financial Services Companies Listed in Indonesia Stock Exchange within 2010- 2013
}

\author{
W. A. Lestari \\ Faculty of Economy \& Business, Telkom University \\ Bandung 40257, Indonesia
}

\author{
A. Krisnawati \\ Faculty of Economy \& Business, Telkom University \\ Bandung 40257, Indonesia
}

\begin{abstract}
This study aimed to analyze the influence of intellectual capital on the financial performance. Intellectual capital is an independent variable, which is represented by the Value Added Intellectual Capital (VAICTM), and financial performance is a dependent variable, which is measured by Return on Assets (ROA), Return on Equity (ROE), Assets Turnover (ATO), and Growth Revenue (GR). This study was conducted by applying the purposive sampling technique on nonfinancial services companies that were listed in the Indonesia Stock Exchange within 2010-2013. The non-financial services companies consisted of 33 companies of Property, Real Estate, and Building Construction Sector; 7 companies of Infrastructure, Utilities, and Transportation Sector; and 44 companies of Trade, Services, and Investment Sector. The study was a descriptiveverificative-study with a panel-data-regression as the analysis technique. The results of this study shows that the intellectual capital significantly influenced ROA and ROE in three sectors, but it significantly affected ATO only in Property, Real Estate, Building Construction Sector, Infrastructure, and Utilities \& Transportation Sector. The intellectual capital also significantly influenced GR only in Property, Real Estate, and Building Construction Sector.
\end{abstract}

Keywords-Capital, Intellectual Capital Value Added (VAICTM), Financial Performance

\section{INTRODUCTION}

The increasing gap between market values and net assets has currently attracted some researchers to reveal the hidden value of intangible assets of firms (Chen et al [1]; Ulum et al [2]; Firer \& Williams [3]). One of the approaches that is commonly used in the study and measurement of intangible assets is Intellectual Capital. It is the focus of attention in many fields, i.e. a good management, information technology, sociology, and accounting (Ulum et al [2]).

In Indonesia, the phenomenon of the intellectual capital began to grow since the advent of Statement of Financial Accounting Standards (Pernyataan Standar Akuntansi Keuangan ï PSAK [4]) No. 19 (Revised 2000) about intangible assets. According to PSAK No. 19 (Revised 2009), intangible assets are non-monetary assets that can be identified without their physical form (non-physical assets). An asset is said to be identifiable if it can be separated or distinguished from the entity and sold, transferred, licensed, rented or exchanged, either individually or together with a related contract, identifiable asset or liability, regardless of whether the entity intends to do or arises from contractual or other legal rights, regardless of whether those rights can be transferred or separated from the entity or from the other rights and obligations [4].

Some concepts of measurement have been created and developed by several researchers to measure the performance of intellectual capital companies, one of which is the model developed by Pulic in Ulum et al [5]. Pulic developed a method, Value Added Intellectual Capital Coefficient (VAICTM) in 1997 to provide information about the value creating the efficiency of tangible assets and intangible assets of a company. The main components of VAICTM are physical capital (VACA - Value Added Capital Employed), human capital (VAHU - Value Added Human Capital), and structural capital (STVA - Structural Capital Value Added) as stated by Ulum [5]. This method is relatively easy and very possible to do, as constructed from the accounts in the financial statements (balance sheet, profit and loss). Zuliyati \& Arya [6] stated that the data needed to calculate various ratios were standard financial figures, generally available in the company's financial statements. VAICTM Model by Pulic is considered to meet the basic needs of the contemporary economy 'measurement system' that shows the true value and performance of a company, because the main objective in the knowledge-based economy is to create value added as suggested by Lasiyono [7].

This study attempted to measure the effect of intellectual capital on the financial performance of the services industries (non-financial) that were listed in the Indonesia Stock Exchange (IDX). The selection of samples was triggered by the phenomenon of growth rate based on the scope of business (sector) in 2013, which were dominated by companies in the services sector such as transport and communications sector; Financial Sector; Real Estate and Business Services; Construction sector; and Trade, Hotel, and Restaurant Sector (Badan Pusat Statistik, 2014). Furthermore, it was found on 
the research of Firer \& Stainbank (2003) that a service industry was categorized in high knowledge-based industries that most intensively used its intellectual capital, while financial sector was not included into the selected samples, as the financial sector was an "old economy" industry, which always used financial assets in its activities as proposed by Abdolmohammadi [8].

Referring to the study of Chen et al [1], Ulum et al [2], and Firer \& Williams [3], the VAICTM model was selected as a proxy of intellectual capital and financial performance that is represented by the Return on Assets (ROA), Return on Equity (ROE), Assets Turnover (ATO), and Growth of Revenue (GR).

\section{LITERATURE REVIEW}

\section{A. Stakeholder Theory}

Ulum [2] stated that the stakeholder theory considers the position of stakeholders who are powerful. Stakeholderôs group is the primary consideration for the company to disclose or to cover information in the financial statements, so that the company will strive to achieve the optimal performance as expected by the stakeholders.

\section{B. Resource-Based Theory}

Organizational resources can be divided into three types, namely physical resources (plant, equipment technology, and the physical, geographical location), human resources (experience and knowledge of employees), and organizational (structure; systems for activity planning; monitoring and control; and social relations within the organization, and between the organization and the external environment). Each of these resources have different contributions in achieving sustainable competitive advantages, so the company should be able to determine the key resources that can create sustainable competitive advantages. Therefore, the companies must realize the importance of managing the intellectual capital that they have, because their intellectual capital can fulfill the criteria as a unique resource that can create a competitive advantage for the company by creating value added to the company's performance as set out by Bassey \& Tapang [9].

\section{Intellectual Capital}

Stewart defined intellectual capital as "the sum of everything known by everybody in your company that gives you a competitive edge in the market place. It is intellectual materials - knowledge, information, intellectual property, experience - that can be put to be used to create wealth ñas stated in Ulum [5].

Purnomosidhi [10] concluded the intellectual capital components also in three elements, namely the intellectual model that is attached to humans (Human Capital/HC), the intellectual capital that is attached to the organization (Structural Capital/SC), and the intellectual capital that is attached to the relationships with external parties (customer capital/CC). Sawarjuwono \& Kadir [11] proposed that SC is an organizationôs or a company's ability that is used in company routines and structures to support employees as the efforts to produce optimal intellectual performances. $\mathrm{HC}$ is the lifeblood of intellectual capital. This is the source of innovation and improvement, but it is also a component that is difficult to measure. $\mathrm{HC}$ is a very useful source like knowledge, skills, and competencies in an organization or company. HC will increase if the company is able to use the knowledge that employees have. Meanwhile, CC is a harmonious relationship or association network that is owned by a company with its partners. It is derived from both reliable suppliers and quality, from the loyal customers who are satisfied with the services of the company concerned, and from the company's relationship with government and with the surrounding community. Relational capital can come from various parts outside the company that can add values to the company.

\section{Value Added Intellectual Coefficient (VAIC ${ }^{T M}$ )}

Ulum et al [2] defined Value Added Intellectual Coefficient (VAICTM) as a method developed by Pulic (1998, 1999 , and 2000) to present information about value creation efficiency of tangible assets and intangible assets owned by a company. This model begins with the company's ability to create value added (VA). VA is the most objective indicator to assess the success of the business and demonstrate the company's ability to create values. The value added is obtained from the variance between the outputs (OUT) and input (IN). VAICTM consists of Value Added Capital Employed (VACA), Human Capital Value Added (VAHU), and Structural Capital Value Added (STVA).

Tan et al [12] stated that the output (OUT) represents the revenue, and covers all products and services sold in the market, while the input (IN) covers the entire expenses used in obtaining revenue. According to Tan et al [12], the importance of this model is the labor expense that is not included in IN. Because of its active roles in the process of value creation, the intellectual potential $\ddot{i}$ which is represented by labor expense $\ddot{i}$ is not counted as expense (cost), and is not included in the IN component as stated by Ulum [2]. Therefore, Tan et al [12] asserted that the key aspect in Pulic model is the treatment of labor as the entity creation of value.

\section{E. Relationship between Value Added Intellectual Coefficient $\left(V A I C^{T M}\right)$ and Financial Performance}

The relationship between intellectual capital and company's financial performances has been demonstrated in a variety of approaches in different sectors of the company as well as in various countries. The following table summarizes some of the research conducted to examine the relationship between intellectual capital and financial performance.

TABLE I. THE EMPIRICAL RESEARCH ON RELATIONSHIP BETWEEN INTELLECTUAL CAPITAL AND FINANCIAL PERFORMANCE

\begin{tabular}{|l|l|l|l|}
\hline Researchers & Country & \multicolumn{1}{|c|}{ Methods } & \multicolumn{1}{c|}{ Result } \\
\hline $\begin{array}{l}\text { Chen et.al } \\
{[1]}\end{array}$ & Taiwan & $\begin{array}{l}\text { VAIC }^{\mathrm{TM}}, \\
\text { correlation } \\
\text { regression }\end{array}$ & $\begin{array}{l}\text { IC affected the market } \\
\text { value and performance of } \\
\text { the company, R\&D } \\
\text { affected the performance of } \\
\text { the company }\end{array}$ \\
\hline $\begin{array}{c}\text { Firer \& } \\
\text { Williams [3] }\end{array}$ & $\begin{array}{l}\text { South } \\
\text { Africa }\end{array}$ & $\begin{array}{l}\text { VAIC } \\
\text { linear } \\
\text { regression }\end{array}$ & $\begin{array}{l}\text { VAIC } \\
\text { with firm performance } \\
\text { (ROA. ATO, MB) }\end{array}$ \\
\hline
\end{tabular}




\begin{tabular}{|l|l|l|l|}
\hline Researchers & Country & \multicolumn{1}{|c|}{ Methods } & \multicolumn{1}{c|}{ Result } \\
\hline $\begin{array}{l}\text { Clarke et.al } \\
{[13]}\end{array}$ & $\begin{array}{l}\text { New } \\
\text { Zealand }\end{array}$ & $\begin{array}{l}\text { VAIC }^{\mathrm{TM}}, \\
\text { correlation, } \\
\text { multiple } \\
\text { regression }\end{array}$ & $\begin{array}{l}\text { IC related to financial } \\
\text { performance, both in the } \\
\text { previous yea, and in the } \\
\text { future }\end{array}$ \\
\hline $\begin{array}{l}\text { Ulum et.al } \\
{[2]}\end{array}$ & Indonesia & $\begin{array}{l}\text { VAIC } \\
\text { PLS }\end{array}$ & $\begin{array}{l}\text { There was a positive } \\
\text { significant relationship } \\
\text { between IC and financial } \\
\text { performance. But the } \\
\text { growth rate of IC did not } \\
\text { affecr the financial } \\
\text { performance in tghe future }\end{array}$ \\
\hline
\end{tabular}

III. TheORETICAL Framework AND HyPOTHESES DEVELOPMENT

\section{A. Relationship between Intellectual Capital and Return on Assets}

If Intellectual Capital (IC) is able to minimize the expenditure, then the company can utilize its assets more efficiently; it will accordingly generate more profits for the company and increase its profitability ratio of Return on Assets (ROA). Thus, the Hypothesis 1 is as follow:

$\mathrm{H}_{1} \quad$ : The Intellectual Capital which is measured by the Value Added Intellectual Coefficient (VAIC $^{\mathrm{TM}}$ ) will significantly impact on the Financial Performance which is measured by Return on Assets (ROA).

\section{B. Relationship between Intellectual Capital and Return on Equity}

If a company can achieve an optimal management of intellectual capital, it will be able to generate greater profits, then it will increase its profitability of Return on Equity (ROE) that will attract investors to invest more money in the company. Thus Hypothesis 2 is as follows:

$\mathrm{H}_{2} \quad$ : The Intellectual Capital which is measured by the Value Added Intellectual Coefficient (VAIC $^{\mathrm{TM}}$ ) will significantly impact on the Financial Performance which is measured by Return on Equity (ROE).

\section{Relationship between Intellectual Capital and Assets Turnover}

With a good management of intellectual capital, the use of assets can be more effective and efficient. Furthermore, the company can produce more qualified services that can increase the amount of revenue and ultimately increase the companyôs ratio of Assets Turnover (ATO). Thus, the Hypothesis 3 is as follow:

$\mathrm{H}_{3} \quad$ : The Intellectual Capital which is measured by the Value Added Intellectual Coefficient $\left(\right.$ VAIC $^{\mathrm{TM}}$ ) will significantly impact on the Financial Performance which is measured by Assets Turnover (ATO).

\section{Relationship between Intellectual Capital and Growth of}

\section{Revenue}

By optimizing intellectual capital, the company will be more productive so that the revenue will also grow well. Thus, the Hypothesis 4 is as follow:

$\mathrm{H}_{4} \quad$ : The Intellectual Capital which is measured by the Value Added Intellectual Coefficient (VAIC $^{\mathrm{TM}}$ ) will significantly impact on the Financial Performance which is measured by Growth of Revenue (GR).

Thus, the theoretical framework that figures the relationship pattern of those variables is as follow:

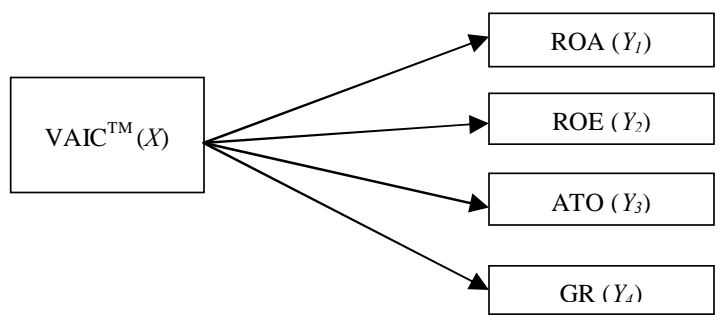

Fig 1. Theoretical Framework

\section{RESEARCH MethodS}

\section{A. Population and Samples}

The population used in this study were all services companies (non-financial) listed in the Indonesia Stock Exchange within the period of 2010 until 2013. The purposive sampling method was conducted in the determination of the samples, which resulted in 84 companies.

\section{B. Independent Variable}

This study used Intellectual Capital (IC) as an Independent Variable with the Value Added Intellectual Capital $\left(\mathrm{VAIC}^{\mathrm{TM}}\right.$ ) as the proxy, and the formulation of VAIC $^{\mathrm{TM}}$ was based on Pulic in Ulum [5] is as follow:

Stage One: Calculating the Value Added (VA).

$\mathrm{VA}$ is calculated as the difference between output and input.

VA $=$ OUT - IN

OUT $=$ Output, total of sales or operating income / business.

IN = Input, total of sales expense or operating costs / effort (other than employee costs)

Two: Calculating the Value Added Capital Employed (VACA). 
VACA is an indicator for the VA that is created by one unit of physical capital. This ratio indicates the contribution made by each unit of $\mathrm{CE}$ to the value added of the organization.

$$
\begin{aligned}
\multicolumn{1}{c}{\text { VACA }=\text { VA/CE }} \\
\text { VACA }=\begin{array}{l}
\text { Value Added Capital Employed }, \text { the ratio of } \\
\text { VA to CE }
\end{array} \\
\mathrm{VA}=\text { Value Added } \\
\mathrm{CE}=\text { Capital Employed, total equity }
\end{aligned}
$$

Stage Three: Calculating the Human Capital Value Added (VAHU).

VAHU shows how much VA can be produced with funds expended for labor. This ratio indicates the contribution made by each amount invested in the $\mathrm{HC}$ to the value added organization.

$$
\text { VAHU }=\text { VA/HC }
$$

VAHU $=$ Value Added Human Capital, the ratio of VA to HC

$\mathrm{VA}=$ Value Added

$\mathrm{HC}=$ Human Capital, labor expense

Stage Four: Calculating the Structural Capital Value Added (STVA).

This ratio measures the number of SC that is required to produce the amount of VA, and it is an indication of how successful the $\mathrm{SC}$ in the creation of the value.

\section{STVA $=$ SC/VA}

STVA = Structural Capital Value Added, the ratio of VA to SC.

$\mathrm{SC}=$ Structural Capital, VA Ï HC

$\mathrm{VA}=$ Value Added

Stage Five: Calculating the Value Added Intellectual $\underline{\text { Coefficient }\left(\mathrm{VAIC}^{\mathrm{TM}}\right)}$

VAIC $^{\mathrm{TM}}$ indicates that an organization's intellectual ability can also be considered as BPI (Business Performance Indicator). $\mathrm{VAIC}^{\mathrm{TM}}$ is the sum of the previous three components: VACA, VAHU, and STVA.

$$
\mathrm{VAIC}^{\mathrm{TM}}=\mathrm{VACA}+\mathrm{VAHU}+\mathrm{STVA}
$$

\section{Dependent Variable}

The dependent variable of this study is financial performance. Financial performance is measured by using the profitability ratios of Return on Assets (ROA) and Return on Equity (ROE), the activity ratio measured by Assets Turnover (ATO), and the growth ratio that is measured by Growth of Revenue (GR).

ROA reflects the firmsôefficiency in utilizing total assets, and holding the constant firmôs financing policy as stated by Chen [1].

According to Keown et al [14], ROA is calculated by the formula as follow:

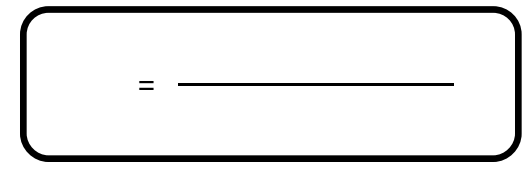

ROE measures the efficiency of the company in generating profits from money invested by shareholders. It is calculated by dividing net income by the number of equity stakeholders as proposed by Ehrhardt \& Brigham [15], with the formula as follow:

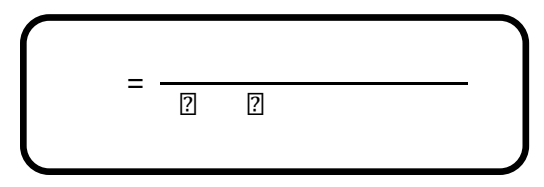

ATO is the ratio of total income or sales to book the value of total assets. This ratio measures how much of the total assets can generate revenue as asserted by Firer \& Williams [3].

Keown et al [14] set out the formula of the ATO as follow:

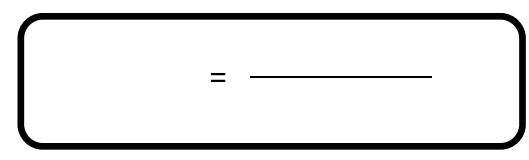

GR measures changes in the company's revenue. The increase in revenue is usually a sign for the company to be able to grow and develop as stated by Chen [1].

The formulation of GR is as follow [1]:

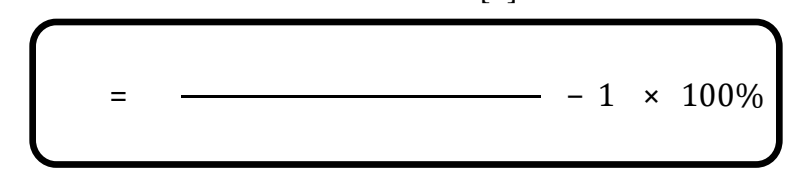

\section{Techniques of Data Analysis}

VAIC $^{\mathrm{TM}}$ formulated by Pulic in Ulum [5] was used to determine the efficiency of the three models of Intellectual Capital (IC), namely physical capital, human capital, and structural capital. Data analysis was conducted with a panel data regression method. The regression analysis was applied in this research to predict the value of the dependent variables caused by the changes of the independent variables. Panel data was a combination of cross-section data and time series data. 
Cross-section data was data collected from multiple objects at one time, while the time series data were data collected from time to time on a single object. Thus, Suliyanto [16] stated that the data collected from multiple objects with multiple time are known as panel data.

After the text edit has been completed, the paper is ready for the template. Duplicate the template file by using the Save As command, and use the naming convention prescribed by your conference for the name of your paper. In this newly created file, highlight all of the contents and import your prepared text file. You are now ready to style your paper; use the scroll down window on the left of the MS Word Formatting toolbar.

TABLE II. PANEl DATA Regression Equation Model to Be Used

\begin{tabular}{|l|l|}
\hline Equations Model 1 & $\mathrm{ROA}=\beta 0+\beta$ VAIC \\
\hline Equations Model 2 & $\mathrm{ROE}=\beta 0+\beta$ VAIC \\
\hline Equations Model 3 & $\mathrm{ATO}=\beta 0+\beta$ VAIC \\
\hline Equations Model 4 & $\mathrm{GOA}=\beta 0+\beta$ VAIC \\
\hline
\end{tabular}

\section{RESUlts AND Discussions}

\section{A. Descriptive Statistics}

Table 3 will show the descriptive statistics on the dependent variable (financial performance) and the independent variables $\left(\mathrm{VAIC}^{\mathrm{TM}}\right.$ ) in the services industries which were divided into 3 sectors, namely Property, Real Estate, Construction \& Building (PRB); Infrastructure, Utilities, and Transportation (IUT); and Trade, Services, and Investment (TSI), which were listed in the Indonesia Stock Exchange within the period of 2010 to 2013.

TABLE III. DESCRIPTIVE STATISTICS

\begin{tabular}{|c|c|c|c|c|}
\hline & & $\begin{array}{c}\text { Property, Real } \\
\text { Estate, \& Building } \\
\text { Construction (PRB) }\end{array}$ & $\begin{array}{l}\text { Infrastructure, } \\
\text { Utilities, \& } \\
\text { Transportation } \\
\text { (IUT) }\end{array}$ & $\begin{array}{l}\text { Trade, Service, } \\
\text { Investment (TSI) }\end{array}$ \\
\hline \multirow{4}{*}{$\mathrm{VAIC}^{\mathrm{TM}}$} & Mean & 6.091289 & 4.514030 & 3.668120 \\
\hline & Maximum & 24.28740 & 11.65371 & 50.01114 \\
\hline & Minimum & 1.944212 & 1.058566 & 1.302022 \\
\hline & Std. Dev. Coef. & 0.597629 & 0.639275 & 1.242814 \\
\hline \multirow{4}{*}{ ROA } & Mean & 6.372001 & 6.352573 & 7.406043 \\
\hline & Maximum & 31.61060 & 16.51000 & 50.95000 \\
\hline & Minimum & 0.540000 & 0.090000 & 0.170000 \\
\hline & Std. Dev. Coef. & 0.644811 & 0.858233 & 0.940620 \\
\hline \multirow{4}{*}{ ROE } & Mean & 12.94115 & 14.82171 & 13.52483 \\
\hline & Maximum & 44.29000 & 55.51000 & 80.89000 \\
\hline & Minimum & -20.34000 & 0.210000 & -3.540000 \\
\hline & Std. Dev. Coef. & 0.718299 & 0.832648 & 0.844996 \\
\hline \multirow{4}{*}{ АТО } & Mean & 0.360164 & 0.388686 & 1.514462 \\
\hline & Maximum & 1.150000 & 1.771656 & 8.110000 \\
\hline & Minimum & 0.030000 & 0.110000 & 0.001254 \\
\hline & Std. Dev. Coef. & & 0.869748 & 0.905163 \\
\hline & Mean & 34.93858 & $\begin{array}{l}40.35833 \\
\end{array}$ & 18.35622 \\
\hline \multirow{5}{*}{ GR } & Maximum & 405.2411 & 253.9582 & 398.8278 \\
\hline & Minimum & -43.76525 & -44.56092 & -59.44052 \\
\hline & Std. Dev. Coef. & 1.535860 & 0.869748 & 2.576225 \\
\hline & Observations & 132 & 28 & 176 \\
\hline & Cross sections & 33 & 7 & 44 \\
\hline
\end{tabular}

Table 3 describes that the data of VAIC ${ }^{\mathrm{TM}}$ of PRB sector are the most homogeneous due to the lowest standard deviation among the three sectors. IUT sector is in the second level, and TSI sector is the highest one $\left(\mathrm{KV}_{\mathrm{PRB}}=0,597629<\right.$ $\left.\mathrm{KV}_{\text {IUT }}=0,639275<\mathrm{KV}_{\text {TSI }}=1,242814\right)$. The same results consistently occur in data of ROA: $\mathrm{KV}_{\mathrm{PRB}}=0,644811<\mathrm{KV}_{\text {IUT }}$ $=0,858233<\mathrm{KV}_{\mathrm{TSI}}=0,940620$; data of $\mathrm{ROE}: \mathrm{KV}_{\mathrm{PRB}}=$
$0,718299<\mathrm{KV}_{\text {IUT }}=0,832648<\mathrm{KV}_{\text {TSI }}=0,844996$; data of ATO: $\mathrm{KV}_{\mathrm{PRB}}=0,756088<\mathrm{KV}_{\mathrm{IUT}}=0,869748<\mathrm{KV}_{\mathrm{TSI}}=$ 0,905163 ; and data of GR: $\mathrm{KV}_{\mathrm{IUT}}=0,869748<\mathrm{KV}_{\mathrm{PRB}}=$ $1,535860<\mathrm{KV}_{\mathrm{TSI}}=2,576225$.

\section{B. Panel Data Regression}

$\underline{\boldsymbol{R O A} \text { and } V \boldsymbol{A I C} C^{T M}}$ : The results of the relationship between ROA and $\mathrm{VAIC}^{\mathrm{TM}}$ are presented in Table 4. The finding showed that there was a positive and significant relationship between them.

TABLE IV. ROA AND VAIC ${ }^{\mathrm{TM}}$

\begin{tabular}{|c|c|c|c|c|c|}
\hline Sector & & Coefficient & t-statistic & $\mathrm{p}$-value & Adjusted $R^{2}$ \\
\hline \multirow{2}{*}{ PRB } & Constant & -0.842304 & -1.506975 & 0.1350 & \multirow[b]{2}{*}{0.740185} \\
\hline & VAIC & 1.184364 & 13.65370 & 0.0000 & \\
\hline \multirow{2}{*}{ IUT } & Constant & 2.423148 & 0.880001 & 0.3869 & \multirow{2}{*}{0.116325} \\
\hline & VAIC & 0.870492 & 2.094556 & 0.0461 & \\
\hline \multirow{2}{*}{ TSI } & Constant & 6.281318 & 7.475475 & 0.0000 & \multirow{2}{*}{0.041563} \\
\hline & VAIC & 0.306622 & 2.924688 & 0.0039 & \\
\hline
\end{tabular}

* Significance $(\alpha)=0,05$

The regression models of the relationship are:

PRB Sector: $\quad \operatorname{ROA}_{\mathrm{PRB}}=$ Ï 0,842304 + 1,184364 VAIC

IUT Sector: $\quad \mathrm{ROA}_{\mathrm{IUT}}=2,423148+0,870492$ VAIC

TSI Sector: $\quad \operatorname{ROA}_{\text {TSI }}=6,281318+0,306622$ VAIC

$\underline{R O E}$ and $V \boldsymbol{A I C} \boldsymbol{C}^{\boldsymbol{T M}}$ : The results of the relationship between $\mathrm{ROE}$ and $\mathrm{VAIC}^{\mathrm{TM}}$ are presented in Table 5. The finding showed that there was a positive and significant relationship between them.

TABLE V. TABLE 5. ROE AND VAICTM

\begin{tabular}{cccccc}
\hline \multirow{2}{*}{ Sector } & & Coefficient & t-statistic & p-value & \multirow{2}{*}{ Adjusted R $^{2}$} \\
\hline \multirow{2}{*}{ PRB } & Constant & 2.435851 & 1.541736 & 0.1256 & \multirow{2}{*}{0.453792} \\
\cline { 2 - 5 } & VAIC & 1.724643 & 10.54972 & 0.0000 & \\
\hline \multirow{2}{*}{ IUT } & Constant & 0.898719 & 0.183937 & 0.8555 & \multirow{2}{*}{0.282553} \\
\cline { 2 - 5 } & VAIC & 3.084381 & 3.464548 & 0.0019 & \\
\hline \multirow{2}{*}{ TSI } & Constant & 11.96458 & 8.670046 & 0.0000 & \multirow{2}{*}{0.028240} \\
\cline { 2 - 5 } & VAIC & 0.425352 & 2.472043 & 0.0144 & \\
\hline
\end{tabular}

* Significance $(\alpha)=0,05$

The regression models of the relationship are:
PRB Sector:
$\mathrm{ROE}_{\mathrm{PRB}}=2,435851+1,724643 \mathrm{VAIC}$
IUT Sector:
$\mathrm{ROE}_{\mathrm{IUT}}=0,898719+3,084381 \mathrm{VAIC}$
TSI Sector:
$\mathrm{ROE}_{\mathrm{TSI}}=11,96458+0,425352 \mathrm{VAIC}$

$\underline{A T O \text { and } V A I C^{T M}}$ : The results of the relationship between $\mathrm{ATO}$ and $\mathrm{VAIC}^{\mathrm{TM}}$ are presented in Table 6 . The finding showed that there was a positive and significant relationship between them in PRB sector, a negative and significant relationship in IUT sector, and there was no significant relationship between them in TSI sector. 
TABLE VI. ATO AND VAICTM

\begin{tabular}{cccccc}
\hline Sector & & Coefficient & t-statistic & p-value & \multirow{2}{*}{ Adjusted R $^{2}$} \\
\hline \multirow{2}{*}{ PRB } & Constant & 0.303440 & 6.067297 & 0.0000 & \multirow{2}{*}{0.067464} \\
\cline { 2 - 5 } & VAIC & 0.009312 & 3.248907 & 0.0015 & \\
\hline \multirow{2}{*}{ IUT } & Constant & 0.630442 & 5.788890 & 0.0000 & \multirow{2}{*}{0.178576} \\
\cline { 2 - 5 } & VAIC & -0.053557 & -2.621021 & 0.0145 & \\
\hline \multirow{2}{*}{ TSI } & Constant & 1.580570 & 8.283645 & 0.0000 & \multirow{2}{*}{0.006286} \\
\cline { 2 - 5 } & VAIC & -0.018022 & -1.460046 & 0.1461 & \\
\hline
\end{tabular}

The regression models of the relationship are:
PRB Sector:
$\mathrm{ATO}_{\mathrm{PRB}}=0,303440+0,009312 \mathrm{VAIC}$
IUT Sector:
$\mathrm{ATO}_{\mathrm{IUT}}=0,630442 \mathrm{ï} 0,053557 \mathrm{VAIC}$
TSI Sector:
$\mathrm{ATO}_{\text {TSI }}=1,580570 \mathrm{I} 0,018022 \mathrm{VAIC}$

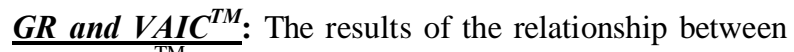
GR and VAIC ${ }^{\mathrm{TM}}$ are presented in Table 7. The finding showed that there was a positive and significant relationship between them in PRB sector, but there was no significant relationship between them in IUT and TSI sector.

TABLE VII. TABLE 7. GR AND VAICTM

\begin{tabular}{|c|c|c|c|c|c|}
\hline Sector & & Coefficient & t-statistic & p-value & Adjusted $\mathrm{R}^{2}$ \\
\hline PRB & Constant & $\begin{array}{r}5.543933 \\
0.566\end{array}$ & 10.71426 & 0.0000 & 0.090654 \\
\hline IUT & Constant & 40.10175 & 1.684436 & 0.1041 & -0.038455 \\
\hline TSI & $\begin{array}{c}\text { VAIC } \\
\text { Constant }\end{array}$ & $\begin{array}{l}0.056840 \\
20.18371 \\
\end{array}$ & $\begin{array}{l}0.012725 \\
3.856952 \\
0.62\end{array}$ & $\begin{array}{l}0.9899 \\
0.0002 \\
0.51616\end{array}$ & -0.003362 \\
\hline
\end{tabular}

* Significance $(\alpha)=0,05$

The regression models of the relationship are:

$\begin{array}{ll}\text { PRB Sector: } & \mathrm{GR}_{\mathrm{PRB}}=5,543933+0,015666 \text { VAIC } \\ \text { IUT Sector: } & \mathrm{GR}_{\mathrm{IUT}}=40,10175+0,056840 \text { VAIC } \\ \text { TSI Sector: } & \mathrm{GR}_{\mathrm{TSI}}=20,18371 \mathrm{ï} 0,498209 \text { VAIC }\end{array}$

\section{FINDINGS AND DisCUSSIONS}

In this research, IC was measured by applying $\mathrm{VAIC}^{\mathrm{TM}}$ method on samples in Indonesian Stock Exchange (IDX), i.e. 33 companies from Property, Real Estate, \& Building Construction Sector; 7 companies from Infrastructure, Utilities, and Transportation Sector; and 44 companies from Trade, Service, and Investment Sector. The empirical finding of this study showed that there were clearly significant positive relationships between $\mathrm{VAIC}^{\mathrm{TM}}$ and ROA; and VAIC $^{\mathrm{TM}}$ and ROE. The same results were consistently found in those three sectors. There was a significant positive relationship between VAIC ${ }^{\mathrm{TM}}$ and ATO in Property, Real Estate, and Building Construction Sector; a significant negative relationship in Infrastructure, Utilities, and Transportation Sector; and there was no significant relationship between VAIC ${ }^{\mathrm{TM}}$ and ATO in Trade, Service, and
Investment Sector. It was also found that there was a significant positive relationship between $\mathrm{VAIC}^{\mathrm{TM}}$ and GR in Property, Real Estate, and Building Construction Sector, but there was no empirical evidence to suggest a relationship between $\mathrm{VAIC}^{\mathrm{TM}}$ and GR in Infrastructure, Utilities, Transportation Sector; Trade, Service, and Investment Sector. In other words, the profitability of a firm was positively influenced by the increase in the value creation efficiency of the intellectual capital. Moreover, findings of this study might be exercised by the managers of companies to utilize and organize the intellectual capital to have additional profitable output.

\section{References}

[1] M.C. Chen, S.J. Cheng, \& Y. Hwang, ñAn Empirical Investigation of the Relationship between Intellectual Capital and Firmsô Market Value and Financial Performanceò. The Journal of Intellectual Capital, Vol. 6, No. 2, 2005, pp. 159-176.

[2] I. Ulum, I. Ghozali, \& A. Chariri, ñIntellectual Capital dan Kinerja Keuangan Perusahaan; Suatu Analisis dengan Pendekatan Partial Least Squaresò. Simposium Nasional Akuntansi (SNA) ke XI, 2008.

[3] S. Firer, \& S.M. Williams, ñIntellectual Capital and Traditional Measures of Corporate Performanceò. The Journal of Intellectual Capital, Vol. 4, No. 3, 2003, pp. 348-360.

[4] Ikatan Akuntan Indonesia, Pernyataan Standar Akuntansi Keuangan No. 19: Aset Tidak Berwujud, 2009.

[5] I. Ulum, Intellectual Capital: Konsep dan Kajian Empiris. Yogyakarta: Graha Ilmu, 2009.

[6] Zuliyati \& N. Arya, ñIntellectual Capital dan Kinerja Keuangan Perusahaanò. Dinamika Keuangan dan Perbankan, Vol. 3, No. 1, 2011, pp. 113-125.

[7] U. Lasiyono, ñPeran Modal Intelektual dalam Praktek Akuntansi Manajemenò, Jurnal Ekonomi Universitas PGRI Adi Buana Surabaya, Volume XVI, Nomer 2, Desember 2012.

[8] M.J. Abdolmohammadi, ñIntellectual Capital Disclosure and Market Capitalizationò, the Journal of Intellectual Capital, Vol 6, No. 3, 2005, pp. 397-416.

[9] B.E. Bassey, \& A.T. Tapang, ñExpensed Human Resources Cost and Its Influence on Corporate Productivity: A Study of Selected Companies in Nigeriaò. The Global Journal of Management and Business Research, Vol. 12, No. 5, 2012, pp. 84-91.

[10] B. Purnomosidhi, ñAnalisis Empiris terhadap Determinan Praktik Pengungkapan Modal Intelektual pada Perusahaan Publik di BEJò. Jurnal TEMA Universitas Brawijaya, Vol 6, No 2, 2005, pp. 111-149.

[11] T. Sawarjuwono, \& A.P. Kadir, ñntellectual Capital: Perlakuan, Pengukuran dan Pelaporan (Sebuah Library Research)ò. Jurnal Akuntansi \& Keuangan, Vol. 5, No. 1, 2003, pp. 35-57.

[12] H.P. Tan, D. Plowman, \& P. Hancock, ñIntellectual Capital and Financial Returns of Companiesò. The Journal of Intellectual Capital, Vol. 8, No. 1, 2007, pp. 76-95.

[13] M. Clarke, D. Seng, \& R.H. Whiting, ñIntellectual Capital and Firm Performance in Australiaò. The Department of Accountancy and Business Law, Working paper series no. 12, 2010.

[14] A.J. Keown, J.D. Martin, J.W. Petty, \& D.F. Scott Jr., Financial Management: Principles and Application $10^{\text {th }}$ Edition. Jakarta: PT Indeks, 2005.

[15] M.C. Ehrhardt, \& E.F. Brigham, E.F., Financial Management: Theory and Practice, $13^{\text {th }}$ Ed. USA: South-Western Cengage Learning, 2011.

[16] Suliyanto, Ekonometrika Terapan: Teori dan Aplikasi dengan SPSS. Yogyakarta: Penerbit Andi, 2011. 